【論文】

\title{
基礎起振実験による岩盤の弾性および減衰特性の評価 \\ EVALUATION OF ELASTIC AND DAMPING CHARACTERISTICS OF BEDROCK BY THE VIBRATION TEST OF THE FOUNDATION
}

\author{
上島照幸*・平田和太头・塩見 哲*** ・渡辺啓行**** \\ By Teruyuki UESHIMA, Kazuta HIRATA, Satoshi SHIOMI \\ and Hiroyuki WATANABE
}

\section{1. まえがき}

構造物の地震時挙動を知るらえで構造物基礎と地盤の 動的相互作用を的確に評価することは重要な課題となっ ている．基礎一地盤系の動的相互作用に対する 理論的研 究は Reissner によって円形基礎の鉛直加振問題に対寸 る解析解が求められて以来， 3 次元弾性論に基づく研究 が数多くなされてきた1).わが国においても田治見の振 動アドミッタンス理論 ${ }^{2}{ }^{2,3)}$ ， 小堀のグラウンドコンプラ イアンス理論4),5) 等をその代表的なものとして挙げるこ とができよう.これら 3 次元弾性論に基ゔく解析解では, 基礎一地盤の動的相互作用特性は地盤の複素ばね， ある いは, ばねーダッシュポットによって評価される.一方， FEM による動的相互作用の解析は，従来この方法の難 点とされていた半無限地盤における地下逸散減衰に対す る評価手法が Lysmer ら ${ }^{6) \sim 1 k)}$ によって提案されて以来, 急速な発展がみられている.これらの手法は半無限地盤 を FEM でモデル化する場合に地盤中に 仮想的に設け られる境界の影響を, 伝達境界, 粘性境界等の設定によ って除去しようとするものである. 周知のごとく，基 礎-地盤系の相互作用の解析にとって地下逸散減衰特性 の正確な評価は重要課題であり, 上記手法の導入によっ て FEM による解析は複雑な地形, 地層構造を有する 地盤に対する動的相互作用を評価するうえで有力な手法 となろう。

以上の理論的研究に対して, 実地盤における基礎一地 盤系の動的相互作用特性を解明する目的で基礎の起振実 験が数多く行われている. 実験例としては比較的軟弱な

* 正会員 工修 (財) 電力中央研究所土木技術研究所

** 正会員 工修 (財) 電力中央研究所士木技術研究所

*** 正会員 工修 (財) 電力中央研究所土木技術研究所

**** 正会員 工博 (財) 電力中央研究所土木技術研究所 (現・埼玉大学助教授 工学部建設基礎工学科)
地盤におけるものは多いが(2) 15)，硬質地盤もしくは岩 盤上での実験例は非常に少なく，小堀らによる実験例 ${ }^{16)}$ をみるのみである。これらの起振実験では基礎挙動から 地盤の複素ばねを算定し，一方では地盤のせん断波速度 をパラメトリックに変化させ, 基礎応答や地盤の複素ば ねに対する 理論值と実験值との 比較等が行われている が，実際の基礎-地盤系においては種々の因子が混入し， たとえば弾性波探査で得られた地盤の物性をもとに理論 から評価した基礎一地盤系の 動的相互作用特性は必ずし も実験結果との良好な一致をみていない，特に理論によ る解釈は実験の定性的な面に止まり, 定量的な面での評 価にはまだ多くの問題を残している.したがって実地盤 における起振実験は単に原位置での基礎-地盤系の動的 相互作用特性を知るためのみならず, 理論解の適用性を 把握するらえでも重要な意味をもつものと思われる.

本論文は上記の観点から岩盤上で基礎の起振実験を行 い, 理論解との比較, 検討を行った結果について述べた ものであるが，特色としては，(1) 表層のせん断波速度 が $700 \mathrm{~m} / \mathrm{s}$ の岩盤上で行われたこと, (2) 起振基礎とし て平面寸法 $14 \mathrm{~m} \times 14 \mathrm{~m}$, 高さ $7.3 \mathrm{~m}$ の大型基礎を設け, 大型構造物基礎に対応できる寸法の基礎で起振実験を行 ったこと, (3) 起振基礎として平面寸法 $4 \mathrm{~m} \times 4 \mathrm{~m}$, 高さ $4.3 \mathrm{~m}$ の小型基礎も設け相互作用特性に及ぼす基礎の寸 法効果の影響を調べたこと，(4) 大型，小型基礎とも， 起振力レベルを変化させた実験を行い, 起振力レベルが 基礎挙動に与える影響を調べ，特に大型基礎に対しては 最大起振力 $150 \mathrm{t}$ の大型起振機を用いたこと, (5) 従来 の起振実験ではおもに基礎の挙動が計測の対象となって いたが，本実験では基礎直下岩盤のひずみ，応答速度の 測定，基䂢の接地圧分布の 測定をも行ったこと，6) 実 験結果を半無限弾性解と比較したのにとどまらず伝達境 界, 粘性境界手法を取り入れた有限要素法によるシミュ レーションを行ったこと, 等が挙げられる. 


\section{2. 実験の概要および実験結果}

\section{（1）実験方法}

図一1に示すように大小 2 種類のコンクリート製基礎 を岩盤上に打設し，基礎起振実験を実施した。 寸法の異 なる基礎を設けたのは岩盤の弾性，減衰特性に対する寸 法効果を検討するためである.

実験地点付近の岩盤は中世代の砂岩，頁岩が互層をな しているが，大小基礎は砂岩帯上に位置し，風化岩を取 り除いて基礎接地面とした. PS 検層によって得られた 大型基礎直下の岩盤の物性値を 表一1 に示す.

小型基礎は平面寸法 が $4 \mathrm{~m} \times 4 \mathrm{~m}$, 高さ $4.3 \mathrm{~m}$, 質量 $166.4 \mathrm{t}$, 大型基礎は平面寸法が $14 \mathrm{~m} \times 14 \mathrm{~m}$, 高さ 7.3 $\mathrm{m}$, 質量 $3406.1 \mathrm{t}$ で, 小型基礎には $\ulcorner 10 \mathrm{t}$ 出力起振機 (起振振動数 $2.0 \mathrm{~Hz} \sim 25.0 \mathrm{~Hz}$, 最大起振力 $10 \mathrm{t}(1 \mathrm{t}=$ $9.8 \mathrm{kN}) ; 12 \mathrm{~Hz}$ 時)」を,大型基礎には「150 t 出力起振 機 (起振振動数 $2.0 \mathrm{~Hz} \sim 20.0 \mathrm{~Hz}$, 最大起振力 $150 \mathrm{t}$ (1 $\mathrm{t}=9.8 \mathrm{kN}) ; 13 \mathrm{~Hz}$ 時)」を使用し, 正弦波定常加振を 行った. 加振方向は岩盤の異方性の影響を調べるため, 両基礎とも水平 2 方向とし，それぞれを $H_{1}$ 方向， $H_{2}$ 方向とした (図一1). 小型基礎では各加振方向とも偏心 モーメント $m_{0} r$ (起振力 $=m_{0} r \omega^{2} \sin \omega t, \omega$ : 起振円振動 数）一定の起振実験を実施し, 応答の起振力依存性を調 べるため偏心モーメントを数段階に変化させた. 大型基 礎では各加振方向に対して起振力一定および最大起振力 で加振した. $\Gamma 150 \mathrm{t}$ 出力起振機」による起振パターンを 図一2 に示寸. 実験は起振振動数を $0.1 \mathrm{~Hz}$ ないし 0.2

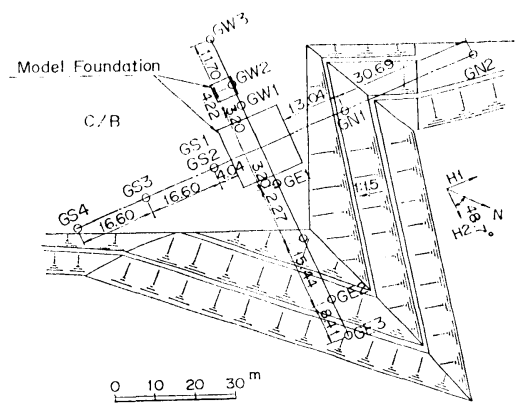

図一1 基砹配踾および地上測点図

表一1 岩 盤物 性 値

\begin{tabular}{|c|c|c|c|c|c|c|}
\hline \multirow{2}{*}{$\begin{array}{c}\text { 深 度 } \\
(\mathrm{m})\end{array}$} & $\mathrm{P}$ 波速度 & $\mathrm{S}$ 波速度 & 密 度 & $\begin{array}{l}\text { ポアリ } \\
\text { ン比 }\end{array}$ & ヤンク率 & 剛性率 \\
\hline & $\begin{array}{c}V_{p} \\
(\mathrm{~km} / \mathrm{s})\end{array}$ & $\begin{array}{c}V_{s} \\
(\mathrm{~km} / \mathrm{s})\end{array}$ & $\begin{array}{c}\rho \\
\left(\mathrm{g} / \mathrm{cm}^{3}\right)\end{array}$ & $\nu$ & $\begin{array}{c}E \\
\left(\mathrm{kgf} / \mathrm{cm}^{2}\right)\end{array}$ & $\underset{\left(\mathrm{kgf} / \mathrm{cm}^{2}\right)}{G}$ \\
\hline $0 \sim 2$ & 2.0 & 0.7 & 2.46 & 0.43 & $\begin{array}{l}\times 10^{5} \\
0.35\end{array}$ & $\begin{array}{l}\times 10^{5} \\
0.12\end{array}$ \\
\hline $2 \sim 5$ & 2.7 & 1.4 & 2.60 & 0.32 & 1.37 & 0.52 \\
\hline $5 \sim 14.3$ & 4.2 & 2.0 & 2.60 & 0.35 & 2.87 & 1.06 \\
\hline
\end{tabular}

$\left(1 \mathrm{~kg} / \mathrm{cm}^{2}=98 \mathrm{kPa}\right)$

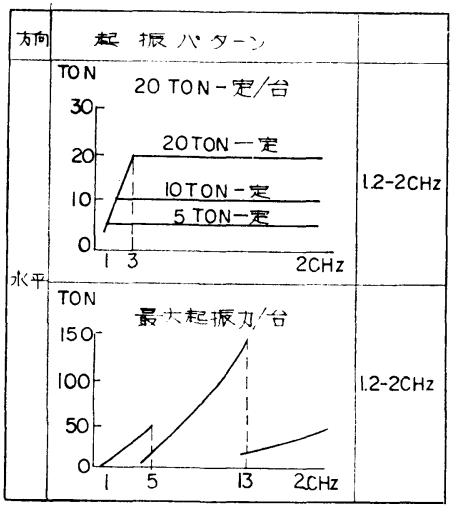

図一2 $150 \mathrm{t}$ 起振機による起振パターン

$\mathrm{Hz}$ 刻みで上昇させ, 各振動数段階において 基礎を定常 加振した. また，起振機からは起振力パルスを発生さ せ, 起振力に対する各種応答の位相差の計測も行った.

\section{（2）計測点および計測方法}

基礎の挙動を調べるため，両基礎に対し図一3に示し た位置に測点を設け動線輪型速度計を設置した．測点配 置は基礎のスウェイーロッキング挙動が完全に計測でき ること，他の振動モード（たとえばねじり振動）が発生 しても検討可能なことを考慮して決定した．また，図一1 に示すように基礎周辺地盤上にも速度計を配置し，起振 実験時の周辺地盤の挙動を調べた.

起振実験時に地盤に発生するひずみを推定するために 大型基礎端 $14 \mathrm{~m}$ 深さのボーリング孔中に速度計および ひずみ計を埋設し，大型基礎中央直下地中 $1 \mathrm{~m}$ 深さの ところには速度計を埋設した．起振実験時には基礎底面 直下ではせん断波が平面波として地中に伝播すると考え られるので，せん断ひずみ $r$ は速度振幅 $\dot{u}$ ，岩盤のせ 儿断波速度 $V_{s}$ を用いて次式により求められる.
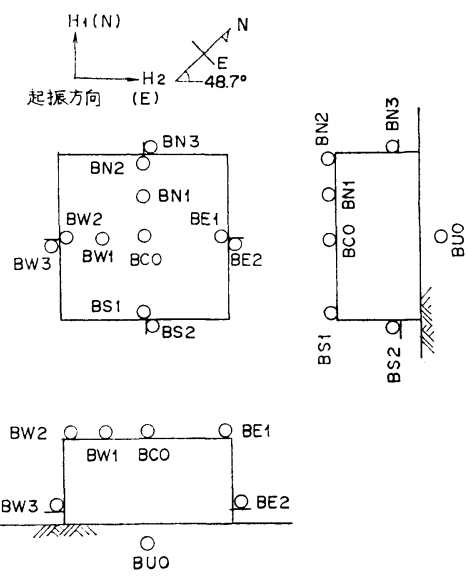

図一3 基嗼上測点配粗図 


$$
r=\frac{\dot{u}}{V_{s}}
$$

また, 基礎と地盤の相互作用の検討には接地圧の分布 形状が重要な因子となるため, 大型基礎直下に土圧計を 設置した。

データの集録, 解析はディジタル計算機を利用して行 い, 時系列データをフーリエ変換し, 振動数, 応答絶対 值, および応答の起振力との位相差を算出した. また, 速度計で計測された応答值は振幅, 位相とも変位に変換 して, 以後の解析に供した.

\section{（3）実験 結 果}

\section{a）基礎の挙動}

図一4, 5 に小型基礎と大型基礎の 共振曲線と位相曲 線の一例を示す. 図中, 測点名の後に続く文字は測定す る運動方向を示し, $N$ は $H_{1}$ 方向を, $E$ は $H_{2}$ 方向を 意味する. 図中には基礎上面と下面における測点での応 答変位および位相遅れ角が比較して示されている. これ らの図より, (1) 基礎上面応答変位は下面応答変位より も大きいこと, (2) 両測点の位相遅れ角はほとんど一致 していること, がわかり, 両基礎とも下心ロッキング振 動しているものと判断できる. また, 起振力作用方向が 偏心した場合に発生する，ねじり振動の影響は無視でき ること,基礎は対称的に振動していることが確認された.

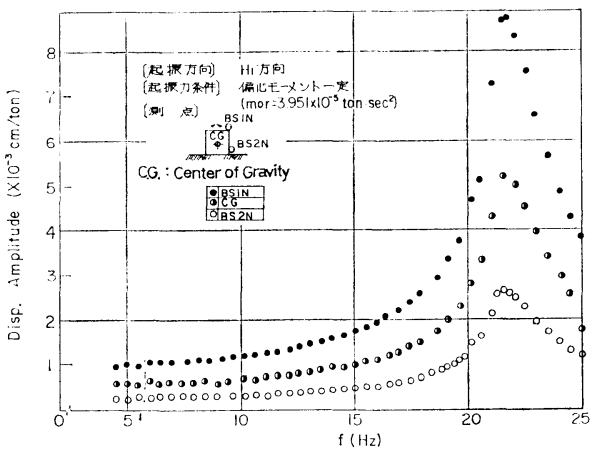

（a）基礎上面, 重心, 下端測点の共振曲線比較

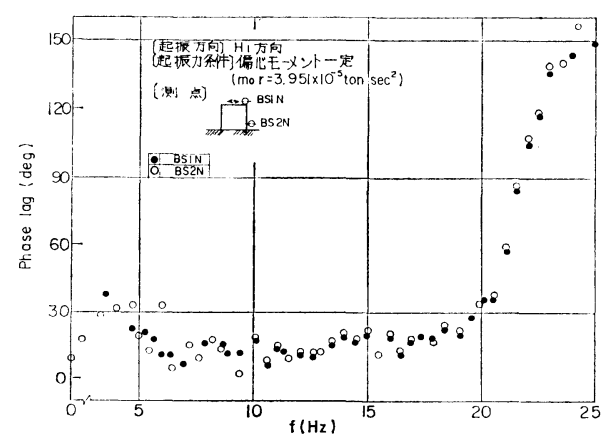

（b）基礎上面, 下端測点位相曲線比較

図-4 小型基礎応答曲線 $(1 \mathrm{t}=9.8 \mathrm{kN})$

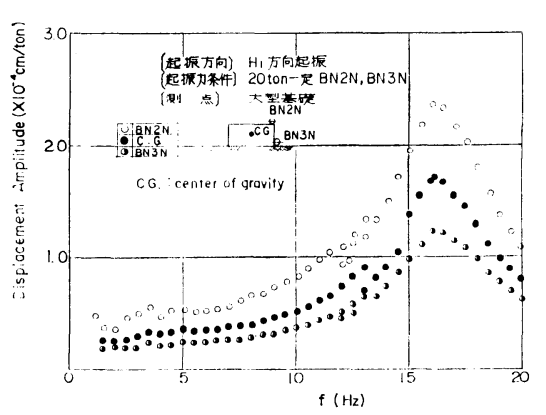

（a）基礎上面，重心，下端測点の共振曲線比較

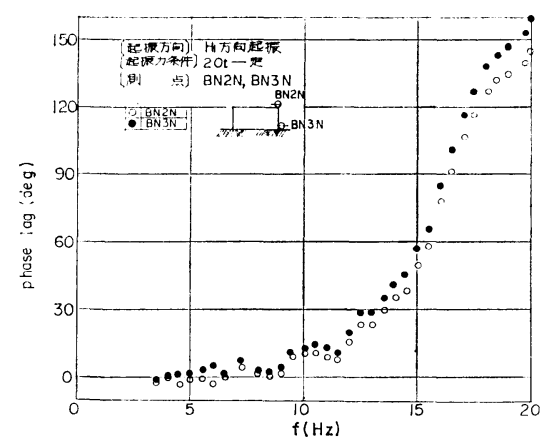

(b) 基礎上面, 下端測点の位相曲線比較

図一5 大型基礎応答曲線 $(1 \mathrm{t}=9.8 \mathrm{kN})$

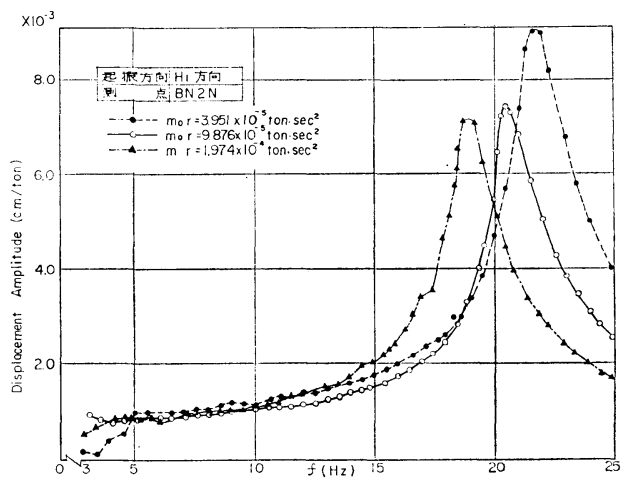

(a) $H_{1}$ 方向

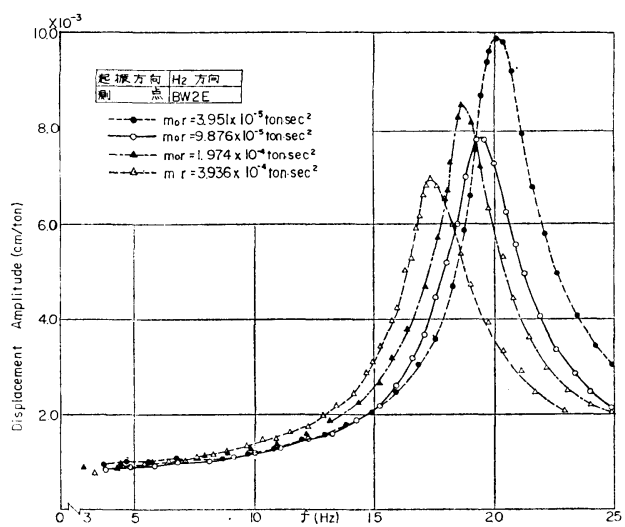

(b) $H_{2}$ 方向

図一6 起振力の変化が基礎応答に与える影塑 （小型基䃈）( $1 \mathrm{t}=9.8 \mathrm{kN}$ ) 


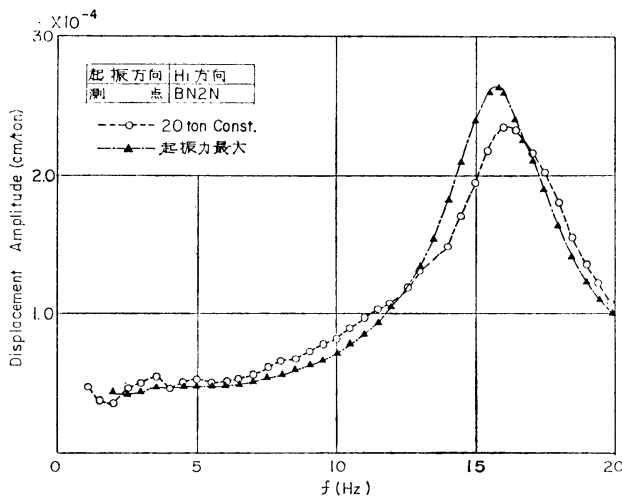

(a) $H_{1}$ 方向

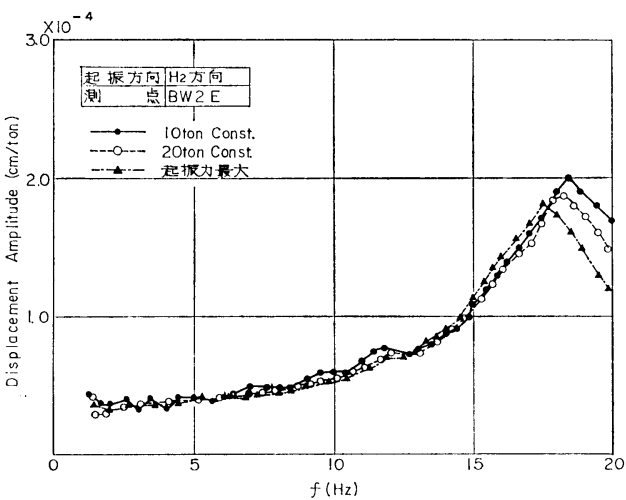

(b) $H_{2}$ 方向

図-1 起振力の変化が基砹応答に与える影餢 (大型基礎) $(1 \mathrm{t}=9.8 \mathrm{kN}$ )

表-2 共振振動数 ${ }^{1)}$, 固有振動数 ${ }^{2}$ および減衰定数

\begin{tabular}{|c|c|c|c|c|c|c|c|c|}
\hline & \multirow{2}{*}{$\begin{array}{l}\text { 起振 } \\
\text { 方向 }\end{array}$} & \multirow{2}{*}{ 起振条件 } & \multirow{2}{*}{$\begin{array}{c}\text { 共振 } \\
\text { 振動 } \\
(\mathrm{Hz})\end{array}$} & \multirow{2}{*}{$\begin{array}{l}\text { 園有 } \\
\text { 振動 } \\
(\mathrm{Hz})\end{array}$} & \multicolumn{2}{|c|}{ 減衰定数（\%) } & \multirow{2}{*}{\multicolumn{2}{|c|}{ 備 }} \\
\hline & & & & & $1 / \sqrt{2}$ 法 & peak法 & & \\
\hline \multirow{6}{*}{$\begin{array}{l}\text { 大 } \\
\text { 型 } \\
\text { 基 } \\
\text { 碳 }\end{array}$} & \multirow{3}{*}{$\begin{array}{c}\text { 水平 } \\
H_{1}\end{array}$} & $5 \mathrm{t}$ 一定 & 17.4 & 17.5 & 11.4 & - & \multirow[t]{3}{*}{ 図-3 } & (BS 1) \\
\hline & & $20 \mathrm{t}$ 一定 & 16.4 & 16.3 & 12.4 & 9.9 & & $(n)$ \\
\hline & & 最 大 & 15.8 & 16.0 & 11.2 & 9.4 & & $(" n)$ \\
\hline & \multirow{3}{*}{$\begin{array}{c}\text { 水平 } \\
H_{2}\end{array}$} & $10 \mathrm{t}$ 一定 & 18.4 & 18.8 & - & 9.5 & \multicolumn{2}{|r|}{ (BW 2) } \\
\hline & & $20 \mathrm{t}$ 一定 & 18.2 & 18.6 & 11.9 & 10.2 & & $(" n)$ \\
\hline & & 最 大 & 17.6 & 17.9 & 12.2 & 10.2 & & $(")$, \\
\hline & \multirow{3}{*}{ 水平 } & $\begin{array}{c}m_{0} r \text { 一定 }^{3)} \\
\left(=3.951 \times 10^{-5}\right)\end{array}$ & 21.8 & 21.8 & 5.5 & 4.3 & \multirow[t]{4}{*}{ 図-3 } & (BS 1) \\
\hline 小 & & $\begin{array}{c}m_{0} r \text { 一定 } \\
\left(=9.876 \times 10^{-5}\right)\end{array}$ & 20.4 & 20.4 & 4.9 & 5.8 & & $(" n)$ \\
\hline & & $\begin{array}{c}m_{0} r \text { 一定 } \\
\left(=1.974 \times 10^{-4}\right)\end{array}$ & 18.9 & 18.9 & 5.6 & 7.1 & & $(" n)$ \\
\hline 型 & $H_{1}$ & $\begin{array}{c}m_{0} r \text { 一定 } \\
\left(=3.936 \times 10^{-4}\right)\end{array}$ & 16.9 & 16.7 & 4.9 & - & & $(" n)$ \\
\hline \multirow[t]{2}{*}{ 基 } & \multirow[b]{2}{*}{ 水平 } & $\begin{array}{c}m_{0} r \text { 一定 } \\
\left(=3.951 \times 10^{-5}\right)\end{array}$ & 20.3 & 20.0 & 6.4 & 4.6 & \multicolumn{2}{|r|}{ (BE 1) } \\
\hline & & $\begin{array}{c}m_{0} r \text { 一定 } \\
\left(=9.876 \times 10^{-5}\right)\end{array}$ & 19.4 & 19.4 & 8.2 & 6.6 & & $(" \prime)$ \\
\hline \multirow[t]{2}{*}{ 礎 } & \multirow[t]{2}{*}{$H_{2}$} & $\begin{array}{c}m_{0} r \rightarrow \text { 定 } \\
\left(=1.974 \times 10^{-4}\right)\end{array}$ & 18.8 & 18.5 & 6.7 & 7.0 & & $(n)$ \\
\hline & & $\begin{array}{c}m_{0} r \text { 一定 } \\
\left(=3.936 \times 10^{-4}\right)\end{array}$ & 17.2 & 17.2 & 7.1 & 8.7 & & $(")$ \\
\hline
\end{tabular}

（注） 1)：共振曲線で最大值を示す振動数

2)：位相曲線で起振力に対して $90^{\circ}$ の位相漣れを示す振動数

3 ）: 起振力 $F$ は $F=m_{0} r \omega^{2} \sin \omega t\left(こ こ に m_{0} r:\right.$ 偏心モーメント, $\omega$ : 起振 円振動数) で求まる. $m_{0} r$ の単位として $\left[\mathrm{t} \cdot \mathrm{s}^{2}\right]$ を探用 $(1 \mathrm{t}=9.8 \mathrm{kN})$
起振力の変化が基礎応答に与える影響を調べるため共振 曲線の重妏書きをしたものを 図一6，7 に示す．起振力 の増加とともに 共振振動数は低下寸る傾向が 認められ る. また，共振時の応答值も起振力とともに減少する傾 向が一部の例外を除いて認められる. 特に小型基礎の場 合には起振力による忘答の非線形性が顕著である.これ らの応答曲線から求めた共振振動数, 固有振動数および 減衰定数を 表一2 に示寸.ここに「共振振動数」は共振 曲線がピークを示す振動数,「固有振動数」は位相曲線 が 90 度を示す振動数という意味で用いている．また， 減衰定数 $h$ は, (1) 共振曲線から $\frac{1}{\sqrt{2}}$ 法で求める方法, (2) 共振曲線のピーク值から 次式で求める方法，を採用 した.

$$
h=\frac{\left(z_{1}+l\right)\left(z_{1}+H-s\right)}{2\left(I_{G}+M z_{1}^{2}\right) Y_{T}} m_{0} r
$$

ここに,

$z_{1}:$ 基礎重心・ロッキング回転中心間距離

$l:$ 基礎重心 $\cdot$ 起振力作用点間距離

$H$ : 基礎高さ

$s:$ 基礎重心 ・接地面間距離

$I_{G}$ : 基礎重心軸回りの質量慣性モーメント（含起振 機)

$M:$ ブロック質量（含起振機）

$Y_{T}$ : 共振時の基礎上面応答変位 表一2 から次のことがわかる。

(1) 大型基䃈，小型基礎の場合とも共振振動数は固有 振動数と概略一致する. 大型基礎では共振振動数 の方が幾分小さく，理論の示す傾向と一致する. また，両基礎とも共振振動数の值は起振力が大き くなるに従って低下し，応答の非線形性を示して いる.

(2) 大型基礎の場合, $H_{2}$ 方向加振の共振振動 数は $H_{1}$ 方向よりも大きく求まった. 大型基礎 設置箇所では，岩盤に $H_{2}$ 方向にほぼ平行な節 理が存在し，節理の方向から考えてこの結果は妥 当と考えられる.すなわち, 節理の影響が岩盤弾 性の異方性に結びついたものと考えられる。ま た，周辺地盤，特に斜面が大型基礎応答に及ぼす 影響は認められなかった。

なお，小型基礎の場合，共振振動数は小起振力 時には $H_{1}$ 方向加振結果が, 大起振力時には $H_{2}$ 方向結果が大きく求まっているため岩盤の異方性 と結びっけて論ずることはできなかった.

(3) 大型基礎の減衰定数は小型基礎に比べ大き な值を示している.これは大型基礎は小型基礎に 比べ偏平な形状で, 大型基礎は小型基礎の場合よ り水平モードが卓越した結果と考えられる（後述 
するように水平方向の減衰定数は回転方向の減衰定数よ り大きな值を示している (図一29，30)).

(4) 大型基礎では減衰定数の起振力依存性は認められ ない，また，加振方向による差異も認められない.

b）地中ひずみ分布

地盤弾性や減哀性は地盤に生ずるひずみ量に依存する といわれ，一般には $10^{-6}$ 程度のひずみ量がその基準に なるといわれている. 起振実験時の基礎挙動がどの程度 の発生ひずみ量までのものかを測定し，基礎応答の非線 形性との関連づけのための資料とした.

図一8 に最大起振力で大型基礎を加振したときに大型 基礎端直下岩盤に発生した圧縮ひずみの応答曲線を樑さ 方向測点について重ねたものを示す. 図では起振力 $1 \mathrm{t}$ $(=9.8 \mathrm{kN})$ 当たりのひずみとして示されているが，実 際に発生したひずみはこの図で示された值の $13 \mathrm{~Hz}$ 時 で 150 倍, $17.5 \mathrm{~Hz}$ 時で 38 倍であり, ひずみのオー ダーとして $10^{-6}$ を越えていないことになる.

図一9に孔中に埋設した速度計で計測した速度值から

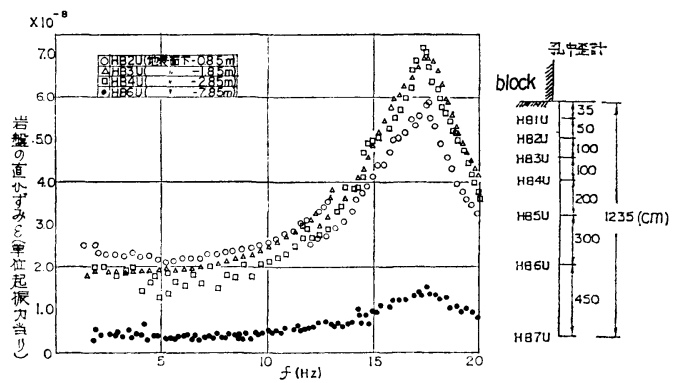

図一8 圧縮ひずみの深さ方向分布
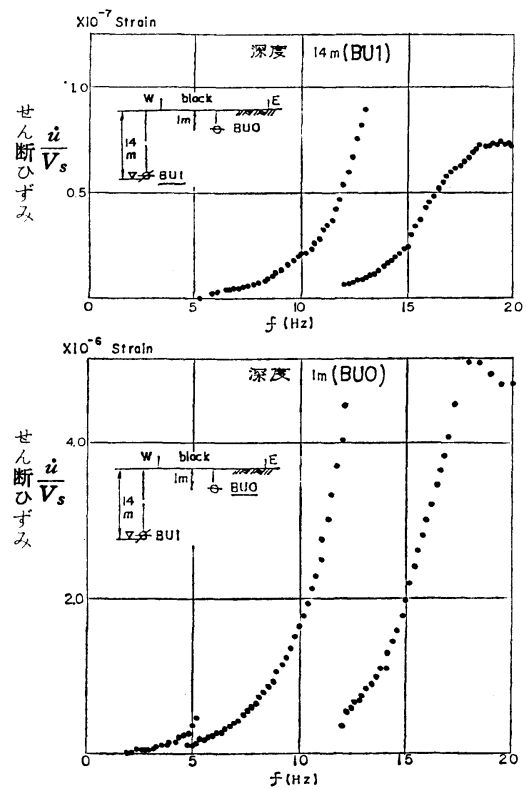

図一9 岩盤のせん断ひずみ

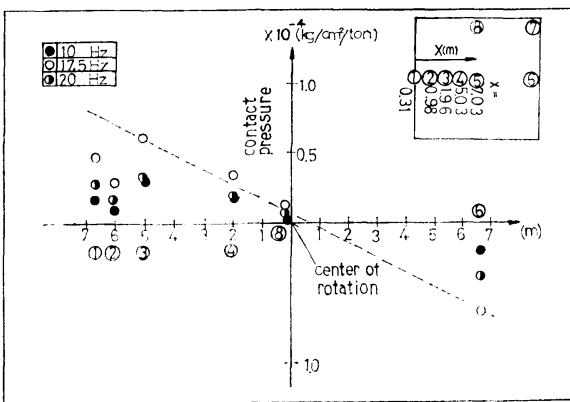

図一10大型基碐接地圧分布 $\left(1 \mathrm{~kg} / \mathrm{cm}^{2}=98 \mathrm{kPa}\right.$, $1 \mathrm{t}=9.8 \mathrm{kN}$ )

式（1）を用いて求めたせん断ひずみの応答曲線を示す. 図より大型基磷中央直下地中 $1 \mathrm{~m}$ 深さに発生したせん 断ひずみのオーダーは $10^{-6}$ で圧縮ひずみと同じ程度で ある.また，地中 $14 \mathrm{~m}$ の深さになると地表付近の 1/50 程度のひずみ量となっている.

以上より起振実験で発生した岩盤のひずみはたかだか $10^{-6}$ オーダーであり，したがって起振力レベルによる 応答の非線形性は，岩盤表層の節理の影響，基礎と岩盤 の接合部近傍における岩盤の局所的な乱れ等に起因する ものと推論される.

c）接地圧分布

本実験では基礎と地盤の剛性は接近しており, 解析時 に採用する接地圧分布を決定する目的で最大起振力加振 時 ( $H_{2}$ 方向) に接地圧分布の測定を行った. 図一10 に 振動数 $10 \mathrm{~Hz}, 17.5 \mathrm{~Hz}$ (共振時), および $20 \mathrm{~Hz}$ 時の起 振力 $1 \mathrm{t}(=9.8 \mathrm{kN})$ 当たりの接地圧分布を示す. 図中 の基礎中心位置における值としては, 測点 EA (5) の土 圧計が作動 しなかったため同一中心線上の測点 EA (8) の值を用いている.この図によれば基礎端近くの測点 EA (1), (2) よりも EA (3) の接地圧が幾分大きな值を示 しているが, EA(1) の対称点 EA (6) の計測結果も参考 にすれば接地圧分布として「三角形分布」で近似できる ものと思われる.

\section{3. 実験結果の解析一岩盤の複素ばねによるモ デル化一}

\section{（1）岩盤の複素ばねによるモデル化}

基礎を支える岩盤を水平ばね $\boldsymbol{K}_{H}\left(=K_{H}+i K_{H^{\prime}}{ }^{\prime}\right)$ ，回 転ばね $K_{R}\left(=K_{R}+i K_{R}{ }^{\prime}\right)$ によりモデル化し，これらの 諸係数 $K_{H}, K_{H}{ }^{\prime}, K_{R}, K_{R}{ }^{\prime}$ を各起振振動数ごとに基礎 の挙動より求める.

定常加振時の基礎重心の水平変位を $u$, 重心回りの回 転角を $\theta$ とすると基礎の スウェイ・ロッキング挙動は 2 自由度系運動方程式として次式で表わされる. 


$$
\begin{array}{r}
{\left[\begin{array}{cc}
M & 0 \\
0 & I_{G}
\end{array}\right]\left\{\begin{array}{l}
\ddot{u} \\
\ddot{\theta}
\end{array}\right\}+\left[\begin{array}{cc}
\boldsymbol{K}_{H} & -s \boldsymbol{K}_{H} \\
-s \boldsymbol{K}_{H} & \boldsymbol{K}_{R}+s^{2} \boldsymbol{K}_{H}
\end{array}\right]\left\{\begin{array}{l}
u \\
\theta
\end{array}\right\}} \\
=m_{0} r \omega^{2}\left\{\begin{array}{l}
1 \\
l
\end{array}\right\} e^{i \omega t} \ldots \ldots \ldots \ldots \ldots \ldots \ldots \ldots \ldots \ldots \ldots \ldots \ldots \ldots \ldots
\end{array}
$$

上式中ドットは時間に関する微分を表わす. $u=U e^{i \omega t}$, $\theta=\theta e^{i \omega t}$ と置いて式 (3) に代入すると $K_{H}, K_{R}$ は次 式で与えられる.

$$
\left.\begin{array}{l}
\boldsymbol{K}_{H}=\frac{m_{0} r \omega^{2}+M \omega^{2} U}{U-s \Theta} \\
\boldsymbol{K}_{R}=\frac{(l+s) m_{0} r \omega^{2}+\omega^{2}\left(s M U+I_{G} \Theta\right)}{\theta}
\end{array}\right\}
$$

$\boldsymbol{K}_{H}, \boldsymbol{K}_{R}$ の各成分は $u, \theta$ に関する 応答の 位相遅れを それぞれ $\varphi_{u}, \varphi_{\theta}$ とすると次式で与えられる.

$$
\begin{aligned}
& K_{H}=\frac{\left[m_{0} r\left(|u| \cos \varphi_{u}-s|\theta| \cos \varphi_{\theta}\right)+M\left\{|u|^{2}-s|u||\theta| \cos \left(\varphi_{u}-\varphi_{\theta}\right)\right\}\right] \omega^{2}}{|u|^{2}+s^{2}|\theta|^{2}-2 s|u||\theta| \cos \left(\varphi_{u}-\varphi_{\theta}\right)} \\
& K_{H}^{\prime}=\frac{\left[m_{0} r\left(|u| \sin \varphi_{u}-s|\theta| \sin \varphi_{\theta}\right)+M s|u||\theta| \sin \left(\varphi_{u}-\varphi_{\theta}\right)\right] \omega^{2}}{|u|^{2}+s^{2}|\theta|^{2}-2 s|u||\theta| \cos \left(\varphi_{u}-\varphi_{\theta}\right)} \\
& K_{R}=\frac{m_{0} r l \omega^{2} \cos \varphi_{\theta}+\omega^{2} I_{G}|\theta|+K_{H^{\prime}} s|u| \sin \left(\varphi_{u}-\varphi_{\theta}\right)+s K_{H}\left[|u| \cos \left(\varphi_{u}-\varphi_{\theta}\right)-s|\theta|\right]}{|\theta|} \\
& K_{R}{ }^{\prime}=\frac{m_{0} r l \omega^{2} \sin \varphi_{\theta}+K_{H^{\prime}}{ }^{\prime} s\left[|u| \cos \left(\varphi_{u}-\varphi_{\theta}\right)-s|\theta|\right]-K_{H} s|u| \sin \left(\varphi_{u}-\varphi_{\theta}\right)}{|\theta|} \\
& h_{H}=\frac{K_{H^{\prime}}}{2 K_{H}}, h_{R}=\frac{K_{R}{ }^{\prime}}{2 K_{R}} \cdots \cdots \cdots \cdots \cdots(6 \cdot \mathrm{a}, \mathrm{b}) \\
& h_{H}=\frac{\Gamma_{2} a_{0}}{4\left(1-\frac{\Gamma_{2}{ }^{2} a_{0}{ }^{2}}{12}\right)}, h_{R}=\frac{\Gamma_{1}{ }^{3} a_{0}{ }^{3}}{24\left(1-\frac{\Gamma_{1}{ }^{2} a_{0}{ }^{2}}{6}\right)} \\
& \Gamma_{1} \doteq 1.212, \quad \Gamma_{2} \doteq 0.912\left(\nu=\frac{1}{3} \text { のとき }\right)
\end{aligned}
$$

\section{（2）半無限弾性解による地盤の複素ばね} は次式で与えられる.

地盤を半無限の一様な弾性体と仮定して, 3 次元弾性 論から地盤の複素ばねが理論的に求められている. 本実

\begin{tabular}{|c|c|c|c|}
\hline \multicolumn{4}{|c|}{ Circular Foundation } \\
\hline & & Uniform & Rigid Base \\
\hline \multirow{3}{*}{ 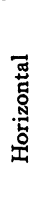 } & $k_{H}$ & $\frac{2 \pi G r}{2-\nu}$ & $\frac{8 G r}{2-\nu}$ \\
\hline & $m_{a}$ & $\frac{1}{12} \cdot \frac{2 \pi G r}{2-\nu}\left(\frac{r \Gamma_{2}}{V_{s}}\right)^{2}$ & $\left(\frac{4}{\pi^{2}}-\frac{1}{4}\right) \frac{8 G r}{2-\nu}\left(\frac{r \Gamma_{2}}{V_{s}}\right)^{2}$ \\
\hline & $C_{H}$ & $\frac{1}{2} \cdot \frac{2 \pi G r}{2-\nu}\left(\frac{r \Gamma_{2}}{V_{s}}\right)$ & $\frac{16}{\pi} \cdot \frac{G r}{2-\nu}\left(\frac{r \Gamma_{2}}{V_{s}}\right)$ \\
\hline \multirow{3}{*}{ 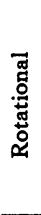 } & $k_{R}$ & $\frac{1}{2} \cdot \frac{\pi G r^{3}}{1-\nu}$ & $\frac{8}{3} \cdot \frac{G r^{8}}{1-\nu}$ \\
\hline & $I_{a}$ & $\frac{1}{12} \cdot \frac{\pi G r^{8}}{1-\nu}\left(\frac{r \Gamma_{1}}{V_{s}}\right)^{2}$ & $\frac{2}{3} \cdot \frac{G r^{8}}{1-\nu}\left(\frac{r \Gamma_{1}}{V_{s}}\right)^{2}$ \\
\hline & $C_{R}$ & $\frac{1}{24} \cdot \frac{\pi G r^{3}}{1-\nu}\left(\frac{r \Gamma_{1}}{V_{s}}\right)^{8} \omega^{2}$ & $\frac{32}{27 \pi} \cdot \frac{G r^{3}}{1-\nu}\left(\frac{r \Gamma_{1}}{V_{s}}\right)^{s} \omega^{2}$ \\
\hline \multicolumn{4}{|c|}{$r:$ radius of foundation } \\
\hline & & $\begin{array}{l}K_{H}=k_{H}-m_{a} \omega^{2} \\
K_{R}=k_{R}-I_{a} \omega^{2}\end{array}$ & $\begin{array}{l}K_{H^{\prime}}=C_{H^{\omega}} \\
K_{R^{\prime}}=C_{R^{\omega}}\end{array}$ \\
\hline
\end{tabular}
験では振動アドミッタンス理論2),3)を用いて実験結果を 整理した. 振動アドミッタンス理論による円形断面基礎 に対する地盤の複素ばね係数を 表一3 に示す.

また, 表一3 中の $K_{H}, K_{H^{\prime}}{ }^{\prime}, K_{R}, K_{R}{ }^{\prime}$ より式 (6)を 用いて得られる減衰定数 $h_{H}, h_{R}$ は次式で示されるよ うに, 無次元化振動数 $a_{0}\left(=\frac{\omega r}{V_{s}}, r\right.$ : 基礎半径 $)$ のみの 関数として表わされる.

(接地圧一様分布)

表一3振動アドミッタンス理論による地盤の 複菜ばね係数
（接地圧剛板分布）

$$
\begin{aligned}
& h_{H}=\frac{\Gamma_{2} a_{0}}{\pi\left[1-\left(\frac{4}{\pi^{2}}-\frac{1}{4}\right) \Gamma_{2}{ }^{2} a_{0}{ }^{2}\right]} \\
& h_{R}=\frac{2 \Gamma_{1}{ }^{3} a_{0}{ }^{3}}{9 \pi\left(1-\frac{\Gamma_{1}{ }^{2} a_{0}{ }^{2}}{4}\right)}
\end{aligned}
$$

\section{（3）実験から得られた地盤の複素ばね, 減衰定数}

a） 低起振力レベルでの試験結果

3. (1) で述べた方法に従い地盤の複素ばね $K_{H}, K_{H^{\prime}}{ }^{\prime}$, $K_{R}, K_{R}{ }^{\prime}$, 減衰定数 $h_{H}, h_{R}$ を算定した. 大型基礎につ いては起振力 $20 \mathrm{t}(1 \mathrm{t}=9.8 \mathrm{kN})$ 一定, 起振方向 $H_{1}$, $H_{2}$ 試験で得られたものを図一11〜図-16 に，小型基 礎については偏心モーメント $m_{0} r=3.951 \times 10^{-5} \mathrm{t} \cdot \mathrm{s}^{2}(1 \mathrm{t}$

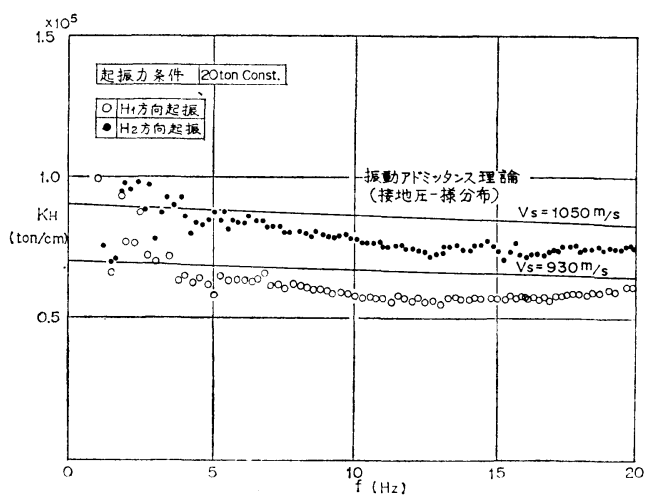

図一11 大型基碮 $\boldsymbol{K}_{H}\left(H_{1}, H_{2}\right.$ 方向 $)$ $(1 \mathrm{t}=9.8 \mathrm{kN})$ 


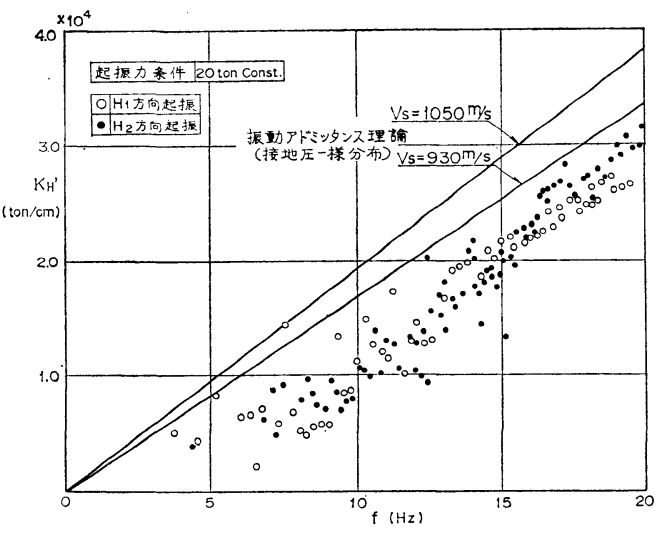

図-12 大型基嗼 $\boldsymbol{K}_{H^{\prime}}\left(H_{1}, H_{2}\right.$ 方向 $)$ $(1 \mathrm{t}=9.8 \mathrm{kN})$

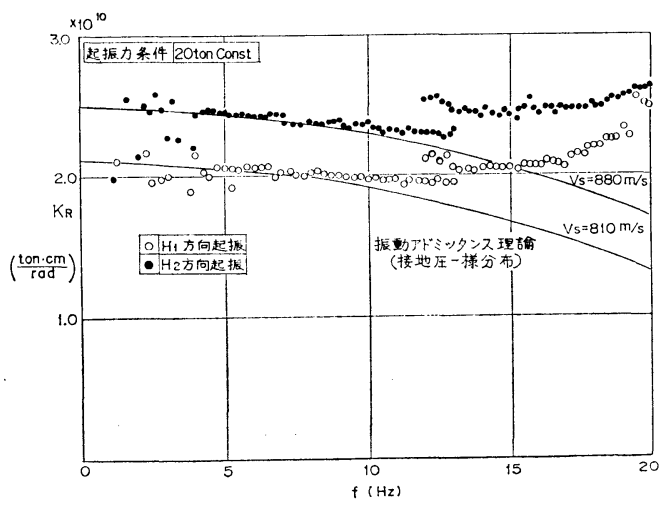

図一13 大型基碐 $\mathrm{K}_{R}\left(\mathrm{H}_{1}, \mathrm{H}_{2}\right.$ 方向 $)$ $(1 \mathrm{t}=9.8 \mathrm{kN})$

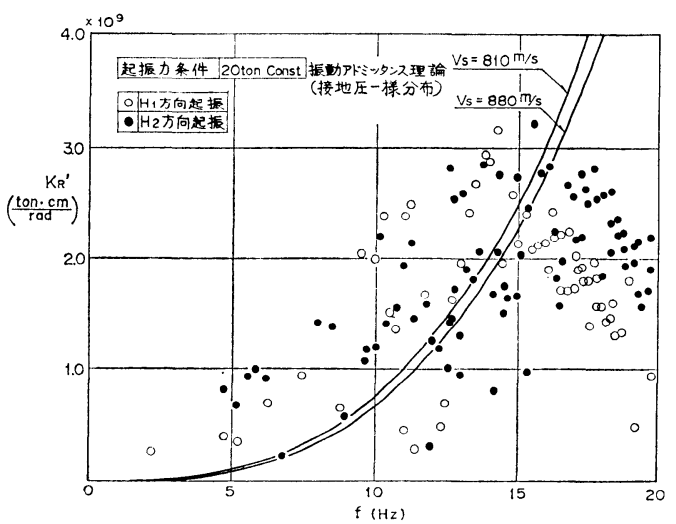

図一14 大型基礎 $\boldsymbol{K}_{R}{ }^{\prime}\left(H_{1}, H_{2}\right.$ 方向 $)$ $(1 \mathrm{t}=9.8 \mathrm{kN})$

$=9.8 \mathrm{kN})$, 起振方向 $H_{1}, H_{2}$ 試験で得られたものを図 -17〜図-22 に示す. これらの図から以下のことがわ かる.

(1) 大型基礎の場合には， $K_{H}, K_{R}$ は起振振動数に 対してほぼ一定の值をとる. $K_{H}{ }^{\prime}$ は起振振動数に対し て直線的に増加し, その結果 $h_{H}$ も起振振動数に対し て直線的に 增加する. $K_{R}{ }^{\prime}$ は全体的にばらつきが大き
く, 起振振動数に対して特定の傾向は みられない. $h_{R}$ は起振振動数によらずほぼ一定の值をとる.

(2) 上記傾向は $H_{1}$ 方向, $H_{2}$ 方向で共通しているが， $H_{2}$ 方向 $K_{H}, K_{R}$ は $H_{1}$ 方向に比べて $20 \sim 30 \%$ 程度 大きめの值をとっている. これは 2.(3) で述べたよう に, $H_{2}$ 方向起振での共振振動数は $H_{1}$ 方向起振の場合 より高めにでるという結果に対応するもので, 岩盤節理 の方向に起因している. $K_{H^{\prime}}, K_{R}{ }^{\prime}$ についても共振振動 数付近では上記と 同様の傾向がみられ，また， $h_{H}, h_{R}$

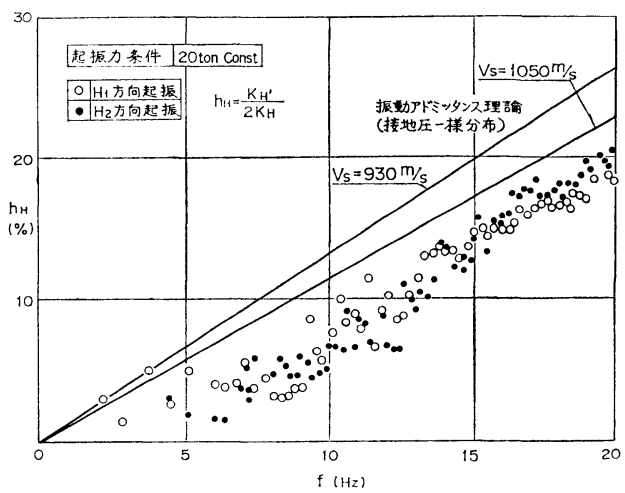

図一15 大型基礎 $h_{H}(1 \mathrm{t}=9.8 \mathrm{kN})$

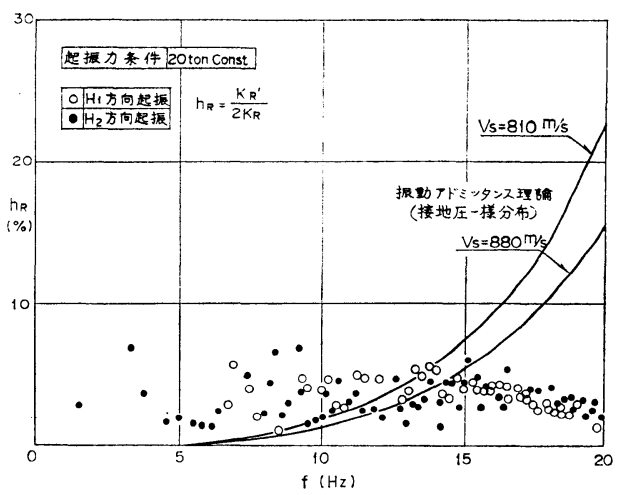

図一16 大型墓砹 $h_{R}(1 \mathrm{t}=9.8 \mathrm{kN})$

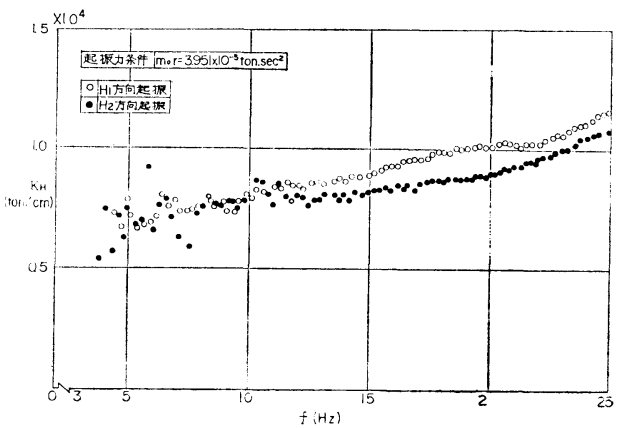

図一17 小型基硔 $\mathrm{K}_{H}\left(\mathrm{H}_{1}, \mathrm{H}_{2}\right.$ 方向 $)$ $(1 \mathrm{t}=9.8 \mathrm{kN})$ 


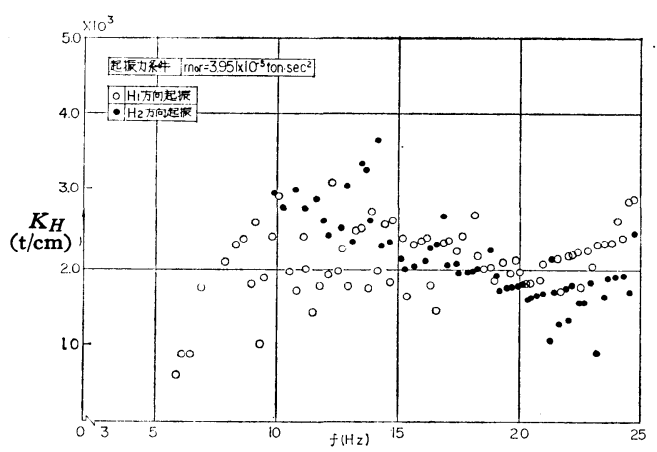

図-18 小型基礎 $K_{H^{\prime}}{ }^{\prime}\left(H_{1}, H_{2}\right.$ 方向 $)$ $(1 \mathrm{t}=9.8 \mathrm{kN})$

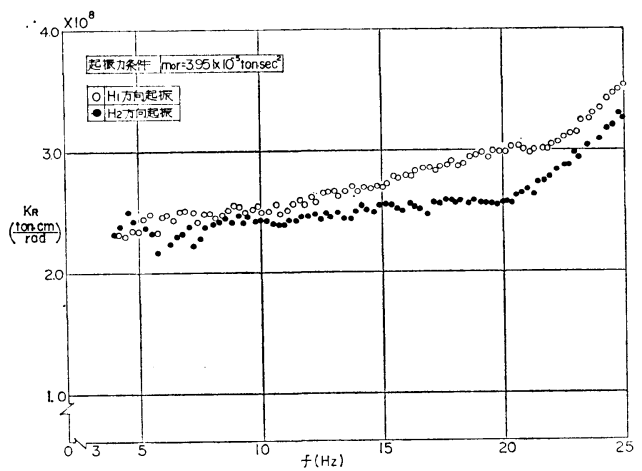

図-19 小型基碮 $\mathrm{K}_{R}\left(H_{1}, H_{2}\right.$ 方向 $)$ $(1 \mathrm{t}=9.8 \mathrm{kN})$

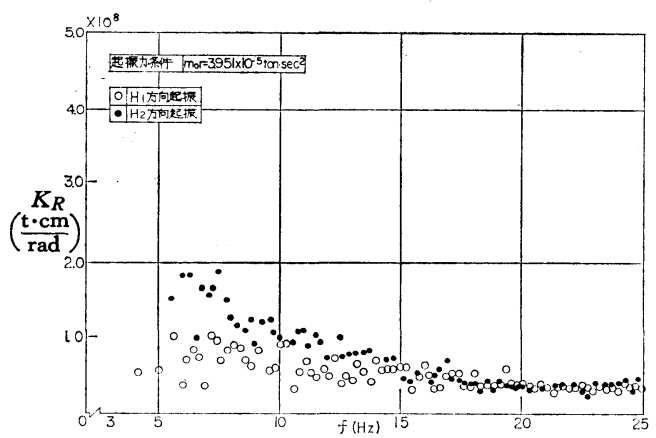

図一20 小型基礎 $K_{R}{ }^{\prime}\left(H_{1}, H_{2}\right.$ 方向 $)$ $(1 \mathrm{t}=9.8 \mathrm{kN})$

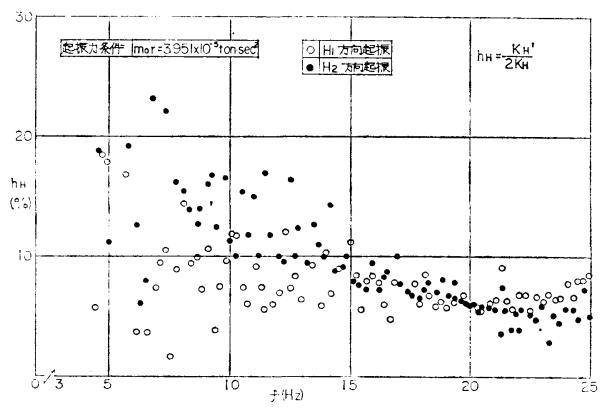

図一21 小型基礎 $\boldsymbol{h}_{H}\left(H_{1}, H_{2}\right.$ 方向 $)$ $(1 \mathrm{t}=9.8 \mathrm{kN})$

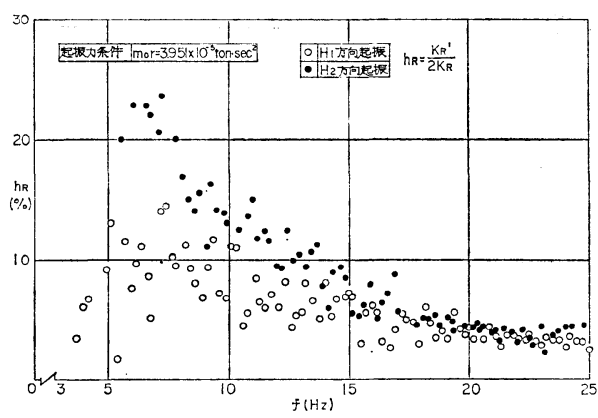

図一22 小型基砹 $\boldsymbol{h}_{R}\left(\mathrm{H}_{1}, \mathrm{H}_{2}\right.$ 方向 $)$ $(1 \mathrm{t}=9.8 \mathrm{kN})$

は $H_{1}$ 方向, $H_{2}$ 方向について同程度の大きさとなる.

(3) 小型基礎の場合には, $K_{H}, K_{R}$ は起振振動数と ともに多少増加寸る傾向にある. $K_{H}{ }^{\prime}, K_{R}{ }^{\prime}$ は低振動数 域では起振振動数とともに減少寸る傾向がみられるが, 高振動数域ではほぼ一定の值を示す. $h_{H}, h_{R}$ について も同様のことがいえる.

b）地盤の複素ばね，減衰定数の起振力依存性

2. (3) で述べたように大型基礎，小型基礎試験とも， 起振力レベルが増大するにつれて共振振動数は低下する 傾向があった.この結果は地盤の複素ばねの起振力依存 性といら形となって現われるが，この傾向をみるため各 起振力レベルでの 地盤の複素ばねの 実数部分 $K_{H}, K_{R}$

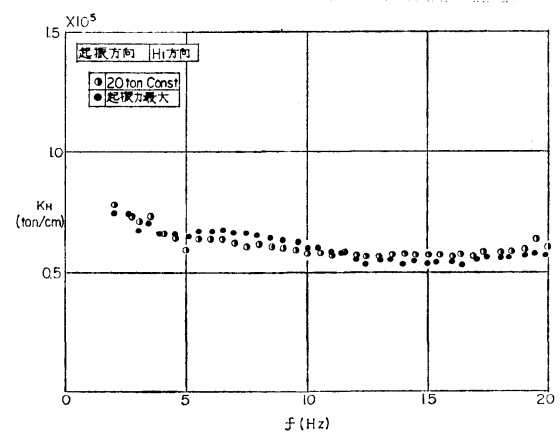

(a) $H_{1}$ 方向

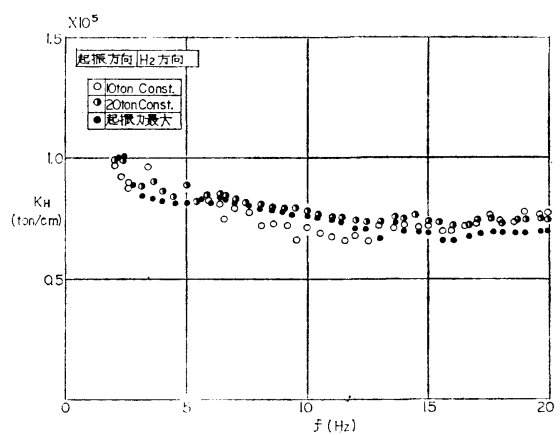

(b) $H_{2}$ 方向

図一23 大型基礎 $K_{H}$ の起振力依存性 $(1 \mathrm{t}=9.8 \mathrm{kN})$ 


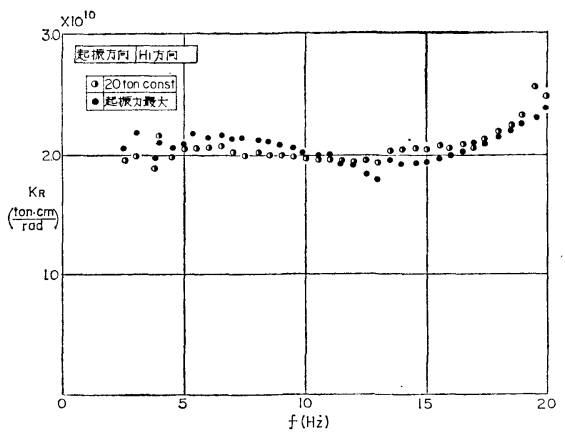

(a) $H_{1}$ 方向

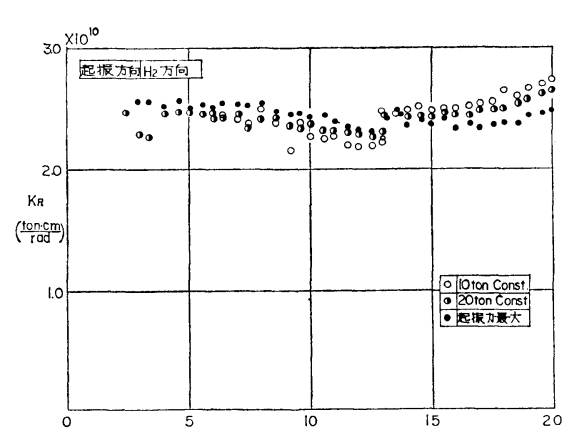

(b) $H_{2}$ 方 向

図一24 大型基礎 $\boldsymbol{K}_{R}$ の起振力依存性 $(1 \mathrm{t}=9.8 \mathrm{kN})$

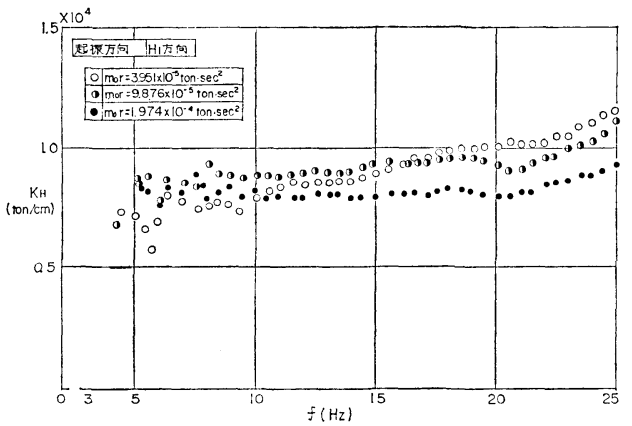

図一25 小型基礎 $\boldsymbol{K}_{H}$ の起振力依存性 $\left(H_{1}\right.$ 方 向) $(1 \mathrm{t}=9.8 \mathrm{kN})$

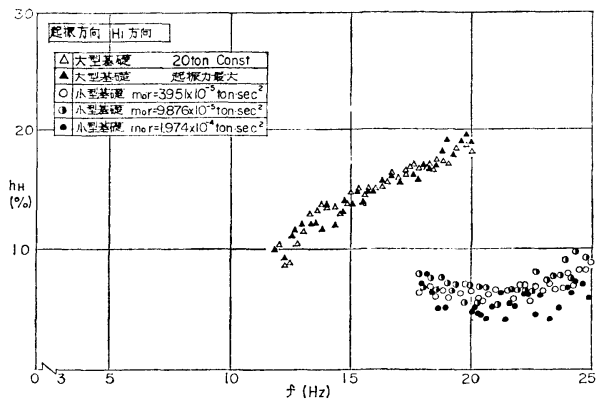

図一27 $\boldsymbol{h}_{H}$ の起振力依存性 ( $H_{1}$ 方 向) $(1 \mathrm{t}=9.8 \mathrm{kN})$

を重ね書きしたものを 図一23〜図一26 に示す. 減衰定 数 $h_{H}, h_{R}$ について同様の整理をしたものを 図一27, 28 に示す.これらの図より以下のことがわかる.

(1) $K_{H}, K_{R}$ の 起振力依存性は大型基礎, 小型基礎 の場合, 振動数領域によって変動はみられるものの, 共 振点付近から上の振動数領域では起振力レベルが上がる につれて $K_{H}, K_{R}$ は低下する傾向にあり, 共振振動数 低下の傾向に 対応している. この傾向は $H_{1}$ 方向, $H_{2}$ 方向に共通している.

(2) $h_{H}$ の起振力依存性は大型基礎，小型基礎とも認 められない. $h_{R}$ の起振力依存性は 大型基礎では認めら れないが，小型基礎では起振力の増大につれて增加する

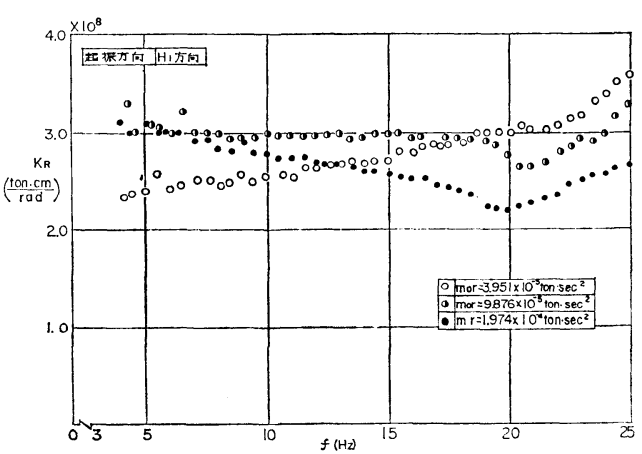

図一26 小型基礎 $K_{R}$ の起振力依存性 $\left(H_{1}\right.$ 方 向) $(1 \mathrm{t}=9.8 \mathrm{kN})$

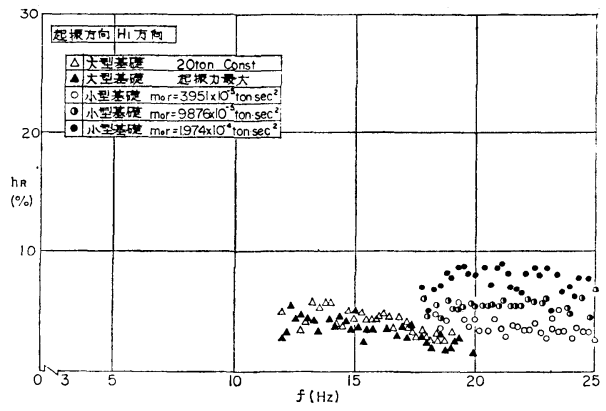

図一28 $h_{R}$ の起振力依存性 $\left(H_{1}\right.$ 方 向) $(1 \mathrm{t}=9.8 \mathrm{kN})$

傾向が認められる.

\section{（4）半無限弾性解による実験結果の検討}

a) 等価 $V_{s}$ の算定

実験から得られた地盤の複素ばねおよび減衰定数を振 動アドミッタンス理論から得られたものと比較する. 振 動アドミッタンス理論は半無限一様地盤に対してて成り立 つものであるが, 本実験は 表一1 に示される層構造を なす岩盤上で行われた．層構造岩盤に対して振動アドミ ッタンス理論を適用するにあたり，これをできるだけ等 価な值を有する一様な岩盤に置き換える．このような観 
点から本実験の場合， 3 層からなる基礎直下の岩盤をそ れと等価なせん断波速度（等価 $V_{s}$ と呼称）を有する一 様 な岩 盤で代表させた． 起振実験結果から岩盤の等価 $V_{s}$ を算定する方法はいくつか考えられるが，ここでは 以下の 2 通りの方法により等価 $V_{s}$ を算定した.

第 1 の方法は岩盤の静的なばね倸数から算定するもの で, 起振実験から求まった $K_{H}, K_{R}$ を外挿し, 振動数 0 における $K_{H}, K_{R}$ の值を求め 表一 3 中の式 $(\omega=0$ とする）に代入して求めるものである. 第 2 の方法は共 振振動数を合わせ得る等価 $V_{s}$ を求めるもので, 共振振 動数における $K_{H}, K_{R}$ を表一3 中の式に代入して求め るものである.また，接地圧分布は一様（または三角 形）分布としたが, これは 2.(3),c) の接地圧分布の測 定結果による. 以上の方法で岩盤の等価 $V_{s}$ を求めると 小型基礎に対する等価 $V_{s}$ は水平動に対して $540 \mathrm{~m} / \mathrm{s} \sim$ $680 \mathrm{~m} / \mathrm{s}$, 回転動に対して $500 \mathrm{~m} / \mathrm{s} \sim 630 \mathrm{~m} / \mathrm{s}$, 大型基礎に 対する岩盤の等価 $V_{s}$ は水平動に対して $820 \mathrm{~m} / \mathrm{s} \sim 1050$ $\mathrm{m} / \mathrm{s}$, 回転動に対して $790 \mathrm{~m} / \mathrm{s} \sim 900 \mathrm{~m} / \mathrm{s}$ の範囲の值をと る $\left(\rho=2.6 \mathrm{~g} / \mathrm{cm}^{3}, \nu=0.36\right.$, 基礎半径は, 正方形基礎と 同面積を有する円形基礎に換算して用いたもの．また， 上述の第 1 , 第 2 の方法によって求めた等価 $V_{s}$ 值をま とめて示したものである).これは層構造をなす岩盤に 対しては小型基礎は表面付近の $V_{s}$ の低い層の影響を大 きく受けるのに対し, 大型基礎では媣部の $V_{s}$ の高い層 の影響をより大きく受けるためと考えられる．また，小 型基䂿に対する等価 $V_{s}$ はPS 検層で得られた最も浅 い層における $V_{s}=700 \mathrm{~m} / \mathrm{s}$ を下回っているが，これは 表層の近傍において掘削時の岩盤の擋乱，ゆるみ等によ る $V_{s}$ のさらに低い層が存在しているためと考えられ， 大型基礎の場合も同様にこの層の影響を受けているもの と思われる.

\section{b）実験值と理論值の対比}

上記の静的 $K_{H}, K_{R}$ から求めた等価 $V_{s}$ を用いて 表 -3 中の式を用いて, 接地圧分布を一様とした場合の振 動アドミッタンス理論による複素ばねと減衰定数を算定 したものが 図一11〜図一16 中に実線で示されている. 水平方向の複素ばね $K_{H}, K_{H}{ }^{\prime}$ は実験值と比較的良好な 一致を示し, $h_{H}$ も実験值は理論值と 同様の傾向を示す が，実験值は理論值より多少低めの值をとる．回転方向 の複素ばね $K_{R}, K_{R}{ }^{\prime}$ は理論值と実験值は特に高い振動 数領域で差が大きく, $h_{R}$ についても同様である. 理論 值と実験值のずれは，実験においては表面付近の岩盤の ゆるみ，岩盤の節理，ブロック隅角部における応力集中 による岩盤の局所的な乱れ等，モデル化が困難な因子が 含まれていること，理論值においては成層岩盤を等価 $V_{s}$ を用いて一様な岩盤に置き換えたことに起因寸るも のと思われる.すなわち，成層岩盤では層間での波の反
射により逸散減衰量が低下し，これが実験值と理論值に おける減衰定数の差となって現われてくるものと思われ る.

c） 無次元化振動数による減衰定数の整理

減衰定数 $h_{H}, h_{R}$ は振動アドミッタンス 理論によれ ば, 式(7), (8)に示されるように無次元化振動数 $\frac{\omega r}{V_{s}}$ の

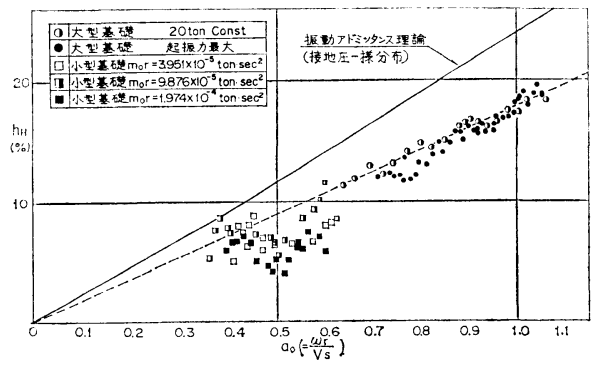

(a) $H_{1}$ 方向

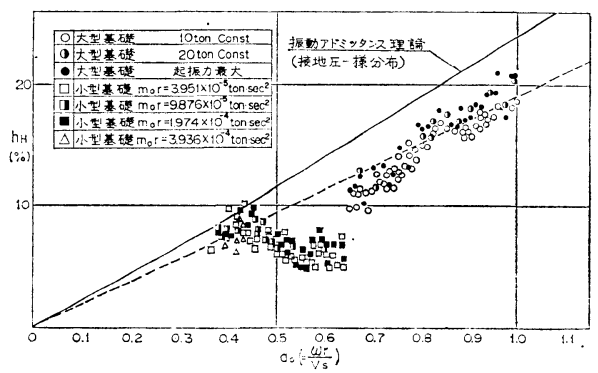

(b) $H_{2}$ 方向

図-29 $\boldsymbol{h}_{H}-\boldsymbol{a}_{0}$ 関係 $(1 \mathrm{t}=9.8 \mathrm{kN})$

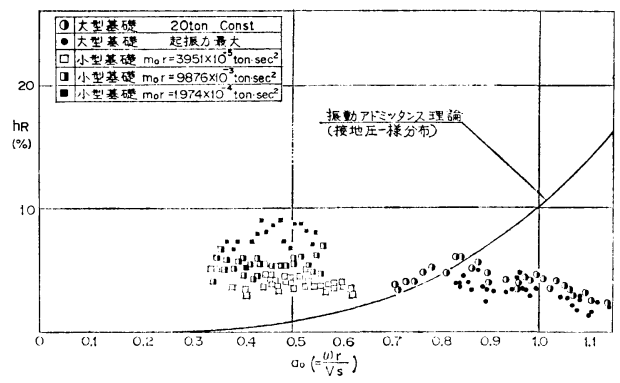

(a) $H_{1}$ 方 向

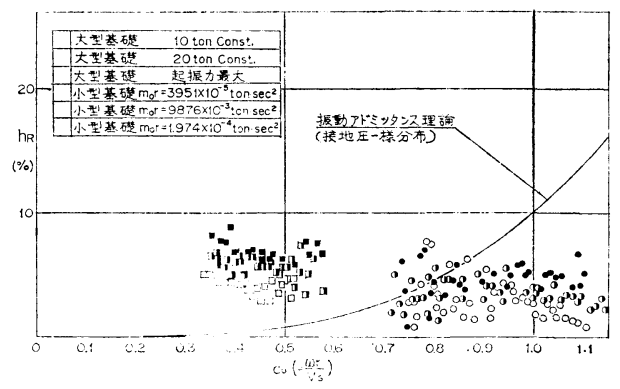

(b) $H_{2}$ 方向

图-30 $\boldsymbol{h}_{R^{-}} \boldsymbol{a}_{0}$ 関係 $(1 \mathrm{t}=9.8 \mathrm{kN})$ 
関数として表わされる. 実験で得られた $h_{H}, h_{R}$ を無 次元化振動数で整理したものを 図一29, 30 に示寸. こ の場合, 等価 $V_{s}$ としては各ケースごとに得られた静的 $K_{H}, K_{R}$ から求めたものを用いた。 図中には式 (7) に よる理論值が併記してあるが， $h_{H}$ については大型基礎 の実験值と理論值が傾向としてはよく一致している．実 験值は理論值より低めの值をとり，これは既述のように 岩盤の層構造の影響と思われるが，実験値と理論值の差 は基礎寸法の増大に伴って減少している. $h_{R}$ について は, 無次元化振動数に対する值の変化は小さく, 大型, 小型基䃈とも同様な值をとり，基礎寸法の影響はみられ ない。

\section{4. 有限要素法による実験結果の解析}

前章で述べた解析手法のほかに, 有限要素法（以下 FEM と記す）によって基礎-地盤系の 動的相互作用を 解析する手法も近年の大型電子計算機の発達と相まって 多用されている．本章では FEM によって起振実験の シミュレーションを行った結果について述べる.

\section{(1) 解析手法}

FEM によって 基礎-地盤系の 動的相互作用の解析を 行う場合, 地盤中に仮想的な境界を設定するため, 境界 面で波動の反射が起こり地下逸散減衰の評価に難点があ るとされてきた. この問題への対応として, 近年, 種々 の手法が検討されているが, Lysmer, Waas らによって 発展させられた伝達境界手法 ${ }^{7}$ １0) や,粘性境界手法(6),11) が代表的なものとして挙げられる.

伝達境界手法とは，構造物近辺の不規則領域を有限要 素モデルによって表現し, 一方, 水平な半無限に広がる 地盤を薄層要素によって表現したうえで, 境界面におけ る応力と変位の連続性を考虑して両者を接続する手法で ある.この手法によれば, 不規則領域の境界を構造物に 十分近い位置にとることができるため, 側方への逸散波 動を考虑に入れつつ不規則領域の節点数を少なく抑える ことができるが，計算手法上の制約から周波数領域での 計算とならざるを得ず，また文献 7)〜10）等で展開さ れている手法をそのまま用いれば，基盤を仮定した計算 とならざるを得なかった。

これに対して粘性境界手法では，側面境界には表面波 による逸散エネルギーを吸収するダンパーを，底面境界 には実体波による逸散エネルギーを吸収するダンパーを 導入するものである.この手法では逸散エネルギー吸収 精度の点から有限要素領域を前者の方法に比べて一定程 度広くとらなければならないが，下方への逸散波動を考 虑できる利点が女る。
著者らは上記両手法のそれぞれの長所を取り入れた計 算プログラムの 開発を行った (以下 'BES’ とよぶ). ‘BES’ では側方への逸散波動に対して，伝達境界手法 ないし粘性境界手法を採用し，そのいずれの場合にも底 面には粘性境界手法を採用寸ることができるよう，手法 の改善を図っている. また三次元的な逸散波動に対して は，擬似三次元化ダンパー息を用いてこれを考慮し得る ようにしている.

\section{（2）起振実験のシミュレーション}

（1）で述べたプログラム 'BES’を用いて起振実験の シミュレーションを行った. 解析には側方伝達境界, 底 面粘性境界, 擬似三次元化ダンパーを使用し, 中央対称 拘束とした. FEM 要素分割図例を 図一31 に示す. モ デル化領域としては深さ，幅を種々変化させて検討を行 ったが，図一31 に示す程度の領城をとれば十分である ことを事前に確認している.

表-1 に示す大型基礎直下の PS 検層で得られた岩盤 物性から出発し, 起振実験時の基礎の挙動を良好に模擬 し得るよう, 地盤物性構造を種々変化させて検討した. 図一32 に起振実験のシミュレーションの流れを示す. また，表一4には解析に使用した岩盤物性值および計算 結果を, 図一-33 にはシミュレーションで得られた大型 基礎の応答曲線を示す. シミュレーションの対象とした 実験ケースは大型基礎については $H_{1}$ 方向起振, 起振力 $20 \mathrm{t}(1 \mathrm{t}=9.8 \mathrm{kN})$ 一定, 小型基礎については $H_{1}$ 方向 起振, 偏心モーメント $m_{0} r=3.951 \times 10^{-5} \mathrm{t} \cdot \mathrm{s}^{2}(1 \mathrm{t}=9.8$ $\mathrm{kN})$ のケースである. 以下にシミュレーションの経過 とその意味ゔけについて述べる.

(1) PS 検層で得られた地盤物性を用いて計算を行っ

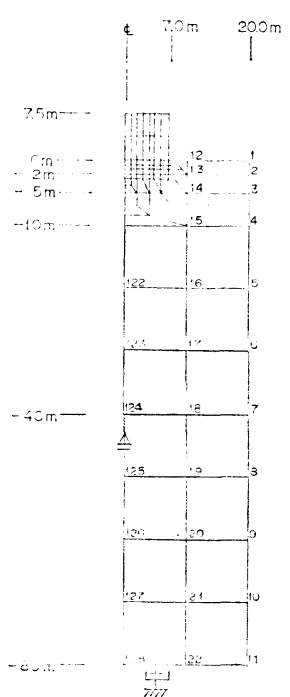

図-31 FEM 要素分割図 （大型基礎） たところ, 実験時の 1 次固有 振動数 $(16.4 \mathrm{~Hz})$ よりもか なり高い周有振動数(>20 $\mathrm{Hz}$ ) を有する結果が得られ （位相遅れでみると， $20 \mathrm{~Hz}$ 時 に，まだ $40^{\circ}$ 程度である）表 層付近の剛性を低下させる必 要性を示唆した（表一4, 図 -33 中の 5-1).

(2) 基礎の水平 ・ 回転連成 振動を模擬する際のおもな指 標として, 固有振動数 $f_{1}$, モード減衰定数 $h_{1}$, 基礎上 面端点の共振時応答変位（水 平変位: $u_{1}, T$, 上下変位: $\left.v_{1}, T\right)$, ルッキング回転半径 在を考える（添字:の 1 は 1 
表一4 各 FEM モデルの地盤定数と計算結果

\begin{tabular}{|c|c|c|c|c|c|c|c|c|c|}
\hline & Iodel & No. & $\begin{array}{l}\text { 変化させた } \\
\text { 対象 層" }\end{array}$ & $\begin{array}{l}\text { 基準 } V_{s}^{*} \\
\text { と }{ }^{*} \text { 比 }\end{array}$ & $\begin{array}{c}f_{1} \\
(\mathrm{~Hz})\end{array}$ & $\begin{array}{c}u_{1, T}, T \\
\left(\times 10^{-6} \mathrm{~m} / \mathrm{t}\right)\end{array}$ & $\left(\times 10^{-6} \mathrm{~m} / \mathrm{t}\right)$ & $\begin{array}{l}z_{1} \\
(\mathrm{~m})\end{array}$ & $\begin{array}{l}h_{1} \\
(\%)\end{array}$ \\
\hline & & $5-1$ & $0 \sim-2 \mathrm{~m}$ & 1 & $>20.0$ & 0.40 & 0.14 & - & - \\
\hline & & $5-2$ & $0 \sim-2 \mathrm{~m}$ & $1 / \sqrt{2}$ & 19.3 & 0.97 & 0.23 & - & - \\
\hline F & 大 & $5-3$ & $0 \sim-2 \mathrm{~m}$ & $1 / 2$ & 14.8 & 2.20 & 0.44 & - & - \\
\hline & & $5-4$ & $0 \sim-5 \mathrm{~m}$ & $1 / \sqrt{2}$ & 18.3 & 1.04 & 0.28 & - & - \\
\hline & & $5-5$ & $0 \sim-2 \mathrm{~m}$ & $1 / \sqrt{3}$ & 17.1 & 1.22 & 0.28 & 24.4 & 13.9 \\
\hline $\mathbf{E}$ & & $5-6$ & $0 \sim-2 \mathrm{~m}$ & $1 / 1.34$ & 15.8 & 1.70 & 0.37 & 23.4 & 11.7 \\
\hline & 型 & $6-2$ & $0 \sim-0.5 \mathrm{~m}$ & $1 / 2$ & 19.9 & 1.59 & 0.428 & 18.4 & 8.32 \\
\hline$M$ & & $6-3$ & $0 \sim-0.5 \mathrm{~m}$ & $1 / 2 \sqrt{2}$ & 16.4 & 2.74 & 0.628 & 23.1 & 6.62 \\
\hline 281 & & $7-1$ & $0 \sim-0.5 \mathrm{~m}$ & $1 / 2 \sqrt{2}$ & 15.8 & 2.4 & 0.615 & 20.5 & 8.4 \\
\hline & 小型 & $2-1$ & $0 \sim-0.5 \mathrm{~m}$ & $1 / 2 \sqrt{2}$ & 21.8 & 66.8 & 19.9 & 4.97 & 4.6 \\
\hline$\underset{\mathrm{X}}{\mathrm{E}}$ & 大 & 型 & - & 一 & 16.4 & 2.35 & 0.95 & 9.37 & 9.5 \\
\hline$\hat{\mathbf{P}}$ & 小 & 型 & - & - & 21.8 & 89.7 & 28.6 & 3.12 & 4.4 \\
\hline
\end{tabular}

* 各 FEM Model の層構造は 表一1 の層構造を基準としている. $(1 \mathrm{t}=9.8 \mathrm{kN})$
同一地盤上に設置された大型，小型 両基礎の実験時挙動を同程度に十分 な精度で模擬し得たことは, 本手法 の有用性を示すものといえよう。ま た，本地点において，さらに大きな 寸法の基礎に対する振動挙動を推定 する場合，実験結果の模擬に用いた 地盤モデルを用いれば十分な精度で 推定可能なものと思われる。

なお，地盤物性修正による試行の 過程で以下のことがわかった．

(1) FEM 解析によって得られた 基礎の固有振動数が起振実験から得 次モード，すなわち下心ロッキング時の量であることを 示す).

実験時の上記諸量を模擬し得るよう，大型基礎につい て地盤物性の修正による試行を重ねた結果, 表層直近の 剛性のみを，検層時の值からゆるめた地盤モデルを用い ると，比較的良好に実験結果を模擬し得ることがわかっ た（表-4 中の 7-1, 図-34). また,この地盤モデル を小型基礎に対して用いた計算では，上記の指標につい て大型基礎とほぼ同程度な精度で実験時基礎挙動を模擬 し得た（表一4 中の 2-1, 図-35).

実験地点の岩盤では, 特に表面付近には応力解放によ る実際の表層ゆるみに加えて種々の不均一性があると考 えられ，また，PS 検層では地表に非常に近い領域の測 定には誤差が伴いやすいことを考えると，地盤モデルに おいて表層直近の剛性をゆるめたことは，これらの影響 を考虑したものといえよう．同一の地盤モデルを用いて

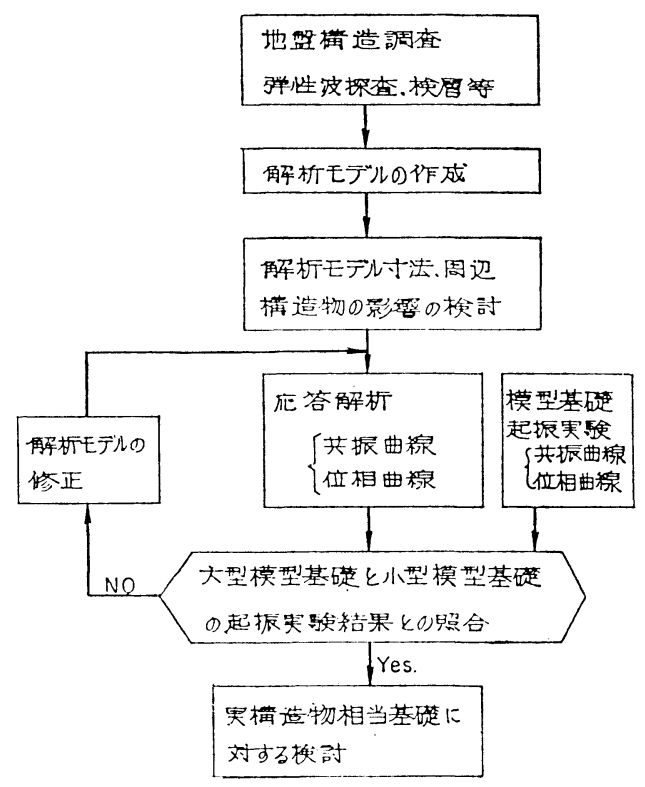

図一32 起振実験シミュレーションの流れ図
られたものより大きい場合には，地盤剛性を低下させれ ばよいが，そのとき低減する層を深くまでとるほど減衰 が大きくなっていく傾向が認められた.

(2) 起振時には，基礎は水平・回転連成振動をしてい るが,このうち, 特に回転動をよりよく模擬するために は, 基礎直下の応力分布の急な変化に対応し得るよう, 要素分割を細かくする必要があり,とりわけ基礎端部で はその必要性が高い. 大型基礎の FEM モデルのらち, メッシュ分割は 3 通り行い, 表一4 中のモデル番号の最 初の数字が $5,6,7$ となる順に基礎付近の要素分割を細 かくしているが，表より要素分割が細かくなるにつれ， 回転半径の模擬性が向上していることがわかる.しかし どのモデルによっても基礎の回転動の模擬性はまだ不十
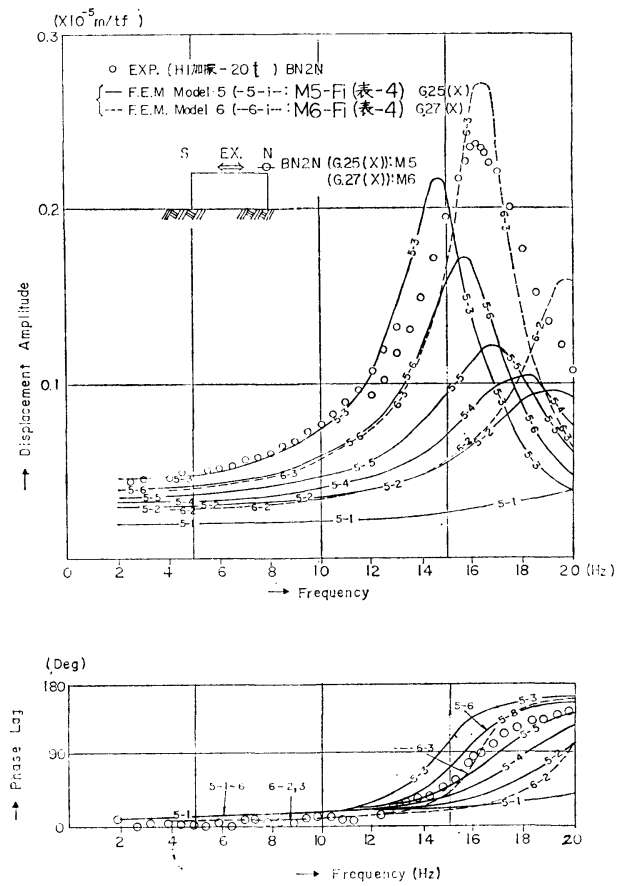
応答曲線 $(1 \mathrm{t}=9.8 \mathrm{kN})$
图-33 シミュレーションによる大型基礎の 
分といえよう（表一4）.

なお，表一4 中に記述した以外の地盤モデルで, 大型 基礎モデル 7-2 よりもさらに忠実に実験時挙動を模提 し得るモデル（たとえば回転半径 $z_{1}$ がより実験時の值 に近い等）も作成して計算している. しかし，回転半径
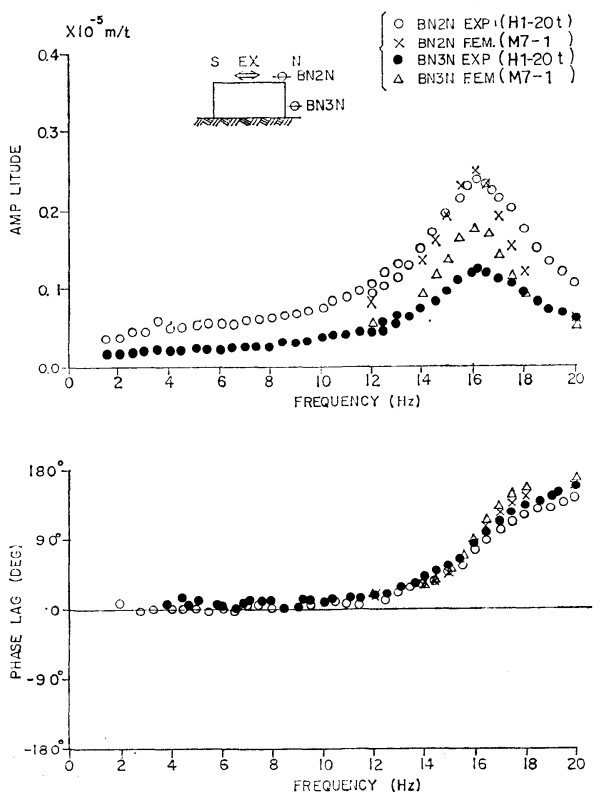

図一-34大型基硞 モデル M 7-1 水平起振時水平 挙動：基礶上面および下端測点（実験と 計算の対比 $)(1 \mathrm{t}=9.8 \mathrm{kN})$

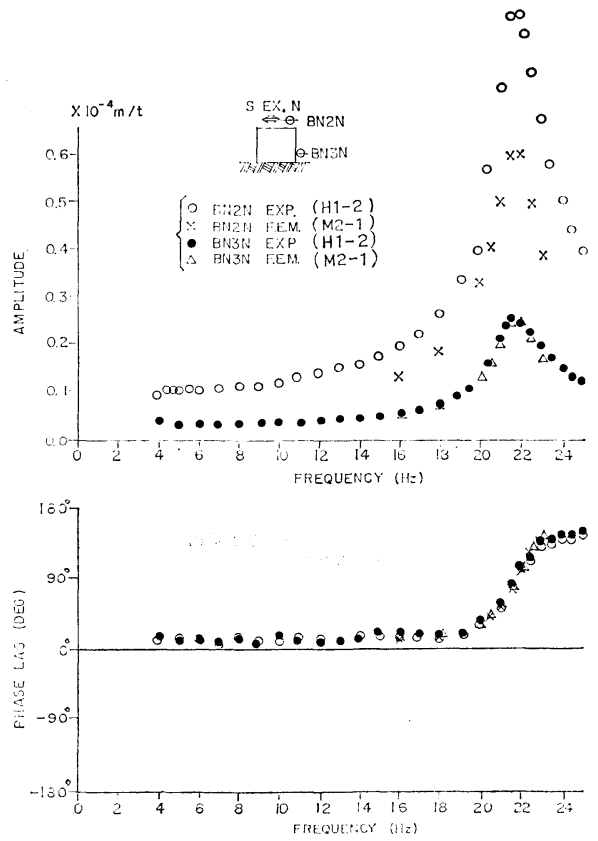

図 -35 小型基礎モデル M 2-1：水平起振時水平 挙動：基桮上面および下端測点（垁験と 計算の対比 $)(1 \mathrm{t}=9.8 \mathrm{kN})$

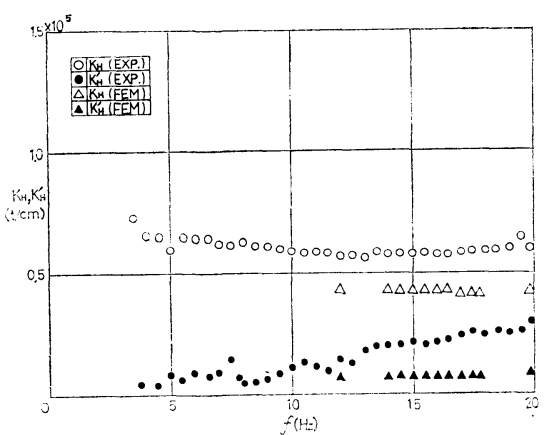

図一36 大型基礎 $\boldsymbol{K}_{H}, \boldsymbol{K}_{H^{\prime}}{ }^{\prime}$ (実験と計算の対比) $(1 \mathrm{t}=9.8 \mathrm{kN})$

を減少させるために，地盤の 剛性分布を成層ではなく し, 基礎端付近で地盤の剛性が低くなるよう剛性の分布 形状を三角形にする等の措置をとっており，こうした方 法では実験時基礎挙動をよりよく模擬し得ても, 大型, 小型両基礎に共通の方式で適用できるとは限らず，結果 の解釈に無理が伴ら可能性があると判断した.

FEM によって計算された 基礎の応答值から，3．で 述べた方法を適用して地盤の複素ばね $K_{H}, K_{R}$ を算定 することにより，FEM と複素ばねモデルの関連付けを 行うことも可能である. 図一36 に実験と FEM によっ て得られた $\boldsymbol{K}_{H}\left(=K_{H}+i K_{H^{\prime}}\right)$ を併記したものを示す.

\section{5. 結 論}

硬質な 岩盤上で 基礎起振実験 を行い，原位置での基 礎一地盤系の動的相互作用特性 を調べるとともに，半無 限弾性体理論 および FEM による検討を行った。 以下 に結論を述べる。

\section{（1）起振実験時の基礎挙動}

水平加振時の基礎は, 起振方向により共振振動数が異 なり，節理の存在が岩盤弾性の異方性の原因となること が認められた。 また，起振力レベルが増大するに従って 共振振動数が低下寸る応答の非線形性がみられたが，岩 盤に発生したひずみレベルは $10^{-6}$ オーダーであり，忍 答の非線形性は表層直近の種々の不整，乱れ等に起因す るものと思われる。文た，本実験においては，基礎と地 盤の剛性は接近していたが，基礎の接地圧分布は三角形 分布で近似できることが認められた。

\section{（2）地盤の複素ばね，減衰定数}

地船の複素ばね $K_{H}, K_{R}$ および減衰定数 $h_{H}, h_{R}$ に ついては, 振動数依存性, 起振力依存性, 起振方向依存 性等の諸特性が得られた。

地盤を一様とみなして “等価 $V_{s}$ ”を用いて半無限弾 
性体理論から求めた地盤の複素ばね, 減衰定数の実験值 との比較を行のた. 水平動に関する諸量 $\boldsymbol{K}_{H}, h_{H}$ は理 論值と実験值との比較的良好な一致をみたが，回転動に 関する $K_{R}, h_{R}$ については必ずしも一致しなかった. また, 基礎寸法が 増加するに従って地盤の “等価 $V_{s}$ ” は大きくなること, 実験值と理論值の差異は小さくなる 傾向にあることが認められた．これらの原因を確定する ことは困難であるが，今後の課題として表層直近の岩盤 物性の評価手法, 成層構造地盤に対する評価手法の確立 等が挙げられよう。

\section{（3）起振実験のシミュレーション}

PS 検層で得られた岩盤のせん断波速度を用いて FE M によるシミュレーションを行った結果，必ずしも実 験結果をよく模擬できず, 実際の岩盤のゆるみ等を考慮 して, 表層直近の物性を変化させた試行計算の結果, 大 型基礎の挙動を比較的良好に模挻し得る地盤モデルを得 た. この地盤モデルを用いると, 小型基礎の挙動に対す る模擬も可能であることがわかり，以上のことから実験 地点と同一の地点での寸法の異なる基礎に対する動的相 互作用特性の推定が可能と考えられる.

謝辞 : 本研究を行うにあたっては東北電力（株） 土木部北松調查役を始めとする同社関倸者各位の多大な 協力を得た. 数值解析においては（株）日本科学技術研 修所霞ヶ関情報センター大阿久聰氏の全面的な協力を得 た. また, 当研究所耐震研究室の室員諸兄には実験から 解析まで終始協力と指導を仰いだ.ここにこれらの方々 に深く感射の意を表すものである.

\section{参考文献}

1) Richart, F.E., Jr. and R.D. Woods : Vibrations of
Soils and Foundations, Prentice-Hall, 1970.

2）田治見宏 : 耐震理論 に関する 基礎研究, 東大生産技術研 究所報告, 第 8 巻, 第 9 号, 1959 .

3）田治見宏ほか：地震工学, 彰国社, 1977.

4）小堀鐸二ほか：長方形基礎の Dynamical Ground Compliance (その 1 ), (その 2), 京大防災研究所年報第 10 号 A, 1972.

5）小堀鐸二ほか：成層構造 をもつ基礎地盤の動特性，京大 防災研究所年報第 19 号 B, 1976.

6) Lysmer, J. and R.L. Kuhlmeyer : Finite Dynamic Model for Infinite Media, ASCE EM 4, Aug. 1969.

7) Lysmer, J. and L.A. Drake : A Finite Element Method for Seismology, Methods in Computational Phy. sics, Vol. 11 : Seismology, Academic Press, 1971.

8) Lysmer, J. and T. Udaka, et al. : A Computer Program for Approximate 3-D Analysis of Soil-Structure Interaction Problems, EERC 75-30, Univ. of California, Nov. 1975.

9) Kausel, E., J.M. Röesset and G. Waas : Dynamic Analysis of Footings on Layered Media, ASCE EM 5, Oct. 1975.

10）田治見宏・下村幸男：3 次元薄層要素による建物-地盤系 の動的解析, 日本建築学会論文報告集 243 号, 1976 年 5 月.

11）花田和史・工藤豊典：地盤-構造物連成系の動的挙動に対 する数值解法, Proc. of the 4th JEES, pp. 311 318, 1975.

12）小堀鐸二ほか：起振実験による基礎構造の振動特性，（そ の 1$) \sim(そ の 4)$, 京大防災研究所年報第 18 号 B, 1975.

13）塩見 哲・堤 一：剛体の起振実験から得られた地盤の 複素ばね特性について, 土木学会第 31 回年次学術講演会 講演概要集, 1976 .

14）塩見 哲・堤 一: 浅い基礎の根入れ効果, 土木学会第 32 回年次学術講演会講演概要集, 1977 .

15）人江康隆ほか：地盤・建物連成系に関する 実験観測的研 究（その 11）一地盤・基礎系におりる等価剛性と等価減 衰係数一, 日本建築学会大会学術講演梗概集, 1981 .

16）小堀鐸二ほか：やや硬質な地盤に扔ける正方形基礎の Dynamical Ground Compliance, 日本建築学会論文報告 集第 305 号, 1981 年 7 月.

(1981.11.25 - 受付) 